\title{
Study of activities of postmen motorcyclists: a look at motorcycle accidents
}

\author{
Lícia Maria Barreto do Nascimento ${ }^{\mathrm{a} * *}$ and Gracielle Aparecida Orlando Bortolotto ${ }^{\mathrm{b}}$ \\ ${ }^{a}$ Serviço Social da Indústria da Bahia - SESI, E-mail: lician@fieb.org.br \\ ${ }^{b}$ Serviço Social da Indústria do Paraná-SESI, E-mail: Gracielle.Orlando@sesipr.org.br
}

\begin{abstract}
This article presents the steps of transforming the material and organizational aspects in the work environment, beyond the social order for the proper development of activities in the Household Distribution Center, the Postmen Motorcyclists. The demand was made by managers from the accident records, establishing the need to identify the working conditions of postmen motorcyclists, regarding motorcycle accidents occurring on public roads. Method: Based on the characteristics of the steps required by the methodology, was necessary to realize internal and external observations, with the aim of identifying the dynamics of the accident and the collective dimensions of activity which requires a strategy for monitoring the work on the street.
\end{abstract}

Keywords: Ergonomics, safety, street work

\section{Introduction}

The Social Services for Industry (SESI) Regional Offices in Bahia and Paraná attend to companies and workers in Industry through Occupational Risk Prevention Programs having ergonomic services as one of its products. This study intends to analyze and propose improvements in the productive process in order to minimize or eliminate problems related to work environment conditions that contribute to accidents suffered by postal motorcyclists.

\section{Method}

Methods based on ergonomic analysis were utilized to study the work situation of postal motorcyclists of the Center for Residential Delivery (CRD) located in the Industrial Center of Curitiba. The focus is on the internal work carried out by the postal deliverers during the sorting of the mail, as well as the external work in the streets carried out in the distribution of the sorted mail. Aspects related to the cause of motorcycle accidents were analyzed, such as public road systems, urbanization policy, traffic, postures, climatic factors and the inter relationship with clients (the population receiving mail).

\section{Findings}

The CRD work team has 52 workers, 10 of whom are motorcyclists. Approximately $80 \%$ of the CDR's work force is less than 40 years old, $77 \%$ are male, $23 \%$ are female, and $65 \%$ have been postal employees for less than 8 years.

The CDR is composed of 32 Postal Districts (PD); eight are serviced by motorcyclists. Each PD has district characteristics. Some have exclusively residential correspondence, others for residential and commercial correspondence, and others exclusively for commercial. The PDs have differentiated numbers of streets within their area. However, there is, in some cases, a sharing of numbering with another PD, that is, two PDs with the same street, being limited by the numbering. PD-461 is the smallest with 20 streets, while PD-491 is the largest with 96 streets.

It was observed that the street activities are more complex and require more attention because of the exposure to dangers which can be aggravated by the amount of time necessary for maneuvering. Each postman develops his distribution strategy depending on the characteristics of the PD, number of points of delivery per street, characteristics of accessibility, traffic, etc. Other factors include variables that interfere in the proper development of the job: rain, points of delivery on the route, group mailboxes, motorcycle maintenance, dogs and street conditions. 


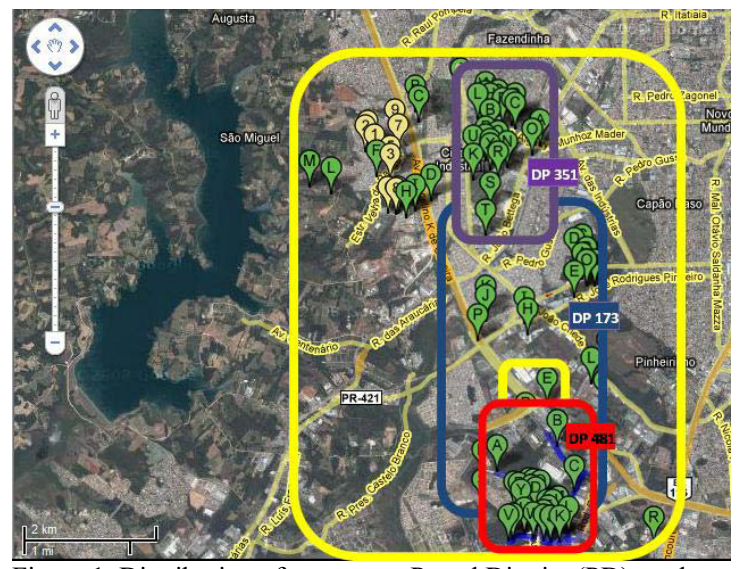

Figure 1. Distribution of streets per Postal District (PD) on the map of the region. Each green symbol indicates a street in the PD.

In 2008, more than $50 \%$ of 197 postal motorcyclist accidents were falls (103 falls, 19 dog bites, 68 collisions and 7 other).

\section{Discussion}

The ergonomic analysis of the postal motorcyclists` work demonstrated that the risk of accidents is a complex phenomenon. The causes of accidents that occurred are in themselves characterize complexity.

The margin of liberty given by the work organization is narrow. It does consider the time demands, the constraints of the external physical spaces, nor the reach of the routes, nor the alteration of operational modes by postal motorcyclists attempting to increase agility in order to gain time.

\section{Conclusion}

The phenomenon of the transit accident involving postal motorcyclists is only not related to the behavior of the driver, but also to the means and rules imposed by managers and clients. The planning of preventive actions must therefore consider all agents and factors that influence the risk propensity to drivers. More prompt actions, decreasingly directed to the motorcyclists' change in behavior, will possibly have little success.

\section{References}

[1] Assunção, A,A; Lima F.P.A A contribuição da ergonomia para a identificação, redução e eliminação da nocividade do trabalho.In: MENDES, R.Patologia do trabalho. 2.ed atualizada e ampliada. São Paulo: Atheneu, 2003.Vol. 2, parte III, Cap. 45.

[2] Dejours, C. A metodologia em psicopatologia do trabalho. In: Lancman, S.; Sznelwar, L. I. (Org.). Cristophe Dejours: da psicopatologia à psicodinâmica do trabalho. Rio de Janeiro: Ed. Fiocruz; Brasília: Paralelo 15, 2004a

[3] Diniz, E.P.H. Assunção, A.A; Lima, F.P.A. Prevenção de acidentes: o (re)conhecimento das estratégias operatórias dos motociclistas profissionais como base para a negociação de acordo coletivo. Ciência e Saúde Coletiva. Rio de Janeiro, 10(4):1-11, 2005

[4] Moraes, T. D. Coletivo de trabalho e atividade dos 'motoboys': gênero profissional, saberes operatórios e riscos da atividade de trabalho. Tese (Doutorado emPsicologia Social) - Programa de Pós-graduação em Psicologia Social, Universidade do Estado do Rio de Janeiro (Uerj). Rio de Janeiro, 2008. 